\title{
Bacteriological analysis of necrotic pulp and fistulae in primary teeth
}

\author{
Antônio Scalco FABRIS, Viviane NAKANO, Mario Julio AVILA-CAMPOS
}

Anaerobe Laboratory, Department of Microbiology, Institute of Biomedical Sciences, University of São Paulo, SP, Brazil.

Corresponding address: Dr. Mario Julio Avila-Campos - Departmento de Microbiologia, Instituto de Ciências Biomédicas, Universidade de São Paulo - Av. Prof Lineu Prestes, 1374 - sala 242 - 05508-900 - São Paulo - SP - Brazil - Phone/fax: 5511 3091-7344/7354 - e-mail: mariojac@usp.br

Submitted: June 13, 2013 - Modification: December 23, 2013 - Accepted: January 13, 2014

\section{ABSTRACT}

$\mathrm{O}$ bjectives: Primary teeth work as guides for the eruption of permanent dentition, contribute for the development of the jaws, chewing process, preparing food for digestion, and nutrient assimilation. Treatment of pulp necrosis in primary teeth is complex due to anatomical and physiological characteristics and high number of bacterial species present in endodontic infections. The bacterial presence alone or in association in necrotic pulp and fistula samples from primary teeth of boys and girls was evaluated. Material and Methods: Necrotic pulp (103) and fistula (7) samples from deciduous teeth with deep caries of 110 children were evaluated. Bacterial morphotypes and species from all clinical samples were determined. Results: A predominance of gram-positive cocci $(81.8 \%)$ and gram-negative coccobacilli (49.1\%) was observed. In 88 out of 103 pulp samples, a high prevalence of Enterococcus spp. (50\%), Porphyromonas gingivalis (49\%), Fusobacterium nucleatum (25\%) and Prevotella nigrescens (11.4\%) was observed. Porphyromonas gingivalis was detected in three out of seven fistula samples, Enterococcus spp. in two out of seven samples, and $F$. nucleatum, $P$. nigrescens and $D$. pneumosintes in one out of seven samples. Conclusions: Our results show that Enterococcus spp. and $P$. gingivalis were prevalent in necrotic pulp from deciduous teeth in boys from 2 to 5 years old, and that care of the oral cavity of children up to five years of age is important.

Keywords: Necrotic pulp. Primary teeth. Enterococcus spp. P. gingivalis. Children.

\section{INTRODUCTION}

Since primary teeth work as guides for the eruption of permanent dentition and contribute to the development of jaws, chewing process, preparing food for digestion and nutrient assimilation, they are important for childhood. Premature loss of teeth can produce change in the eruption guide of the permanent tooth, which can cause phonetic disturbances and harmful oral habits, such as tongue interposition, and aesthetic consequences ${ }^{3}$.

Dental biofilm on occlusal surfaces of primary teeth is associated to active carious lesions ${ }^{2}$. The exposure of pulp tissue to the oral environment will allow that oral microorganisms have access into pulp chamber, producing necrosis ${ }^{10}$.

The treatment of pulp necrosis, particularly in primary teeth, is very complex due to anatomical and physiological characteristics, making the access to the root canal difficult ${ }^{13}$. Treatment of primary endodontic infections is based on the elimination of the root canal infection; although no protocol or techniques for canal instrumentation have been observed ${ }^{16}$. Bacterial species such as Enterococcus faecalis has been reported in high prevalence in primary endodontic infections affecting Turkish children ${ }^{15}$.

The presence of different bacteria involved in endodontic infections of primary teeth, such as pulpitis, pulp necrosis and apical lesion has been reported $17,20,21$; however, microbiological data of fistula are scarce.

Anaerobic bacteria, especially black-pigmented gram-negative rods, are implicated in the development of the acute periradicular inflammation, producing symptoms such as pain, swelling, tenderness and exudation ${ }^{12}$. Microorganisms found in the root canals of primary teeth are similar to those in the root canals of permanent teeth, and black-pigmented anaerobes have been isolated 
(30\% to $50 \%$ ) from endodontic infections ${ }^{24}$, but no relationship between any bacterial species and the etiology of pulp infection have been showed, although there is evidence that black-pigmented anaerobes are implicated in the development of acute periradicular inflammation ${ }^{26}$. In this study, the bacterial presence and the different morphotypes in necrotic pulp and fistula from primary teeth were determined.

\section{MATERIAL AND METHODS}

\section{Patients and clinical samples}

A total of 110 children (69 boys and 41 girls), aged from 2 to 12 years old, with clinical and radiographic signs of necrotic pulp or fistula, observed at the School of Dentistry of the Federal University of Espírito Santo (Vitória, ES, Brazil), were selected. All children presented primary teeth with deep dental caries and dental pulp exposed to oral environment. Some children presented vestibular fistula in gingival area. A single clinical sample was collected per child. No child used antibiotics at least three months prior to the sample collection. Children presenting intact teeth, dental pain at oral examination or any chronic disease were excluded.

Necrotic pulp samples (35 maxilla and 68 mandible region) from 103 children, and gingival fistulas (6 maxilla and 1 mandible region) from 7 children were collected. Necrotic pulp or fistula samples were collected by using two sterile paper points (No. 15, Dentsply, Petrópolis, RJ, Brazil). Initially, tooth and pulp chamber were isolated by rubber dam and the tooth and the surrounding field were cleansed with $3 \%$ hydrogen peroxide and decontaminated with a $1 \%$ sodium hypochlorite solution for $1 \mathrm{~min}$. The sterility of the tooth surface after cleaning and disinfection was evaluated by samples taken from the surface and processed by PCR. Before collecting fistula sample, antisepsis with iodine (2\%) for $1 \mathrm{~min}$ was performed. Sodium hypochlorite and iodine solutions were neutralized with sodium thiosulfate $(5 \%)$ for $30 \mathrm{~s}$. In dry root canal, one drop of sterile saline $(0.9 \%)$ was added, avoiding flooding ${ }^{27}$. The paper points were left in wet canal for $60 \mathrm{~s}$ and then transferred to tubes containing $250 \mu \mathrm{L}$ of TE. All clinical samples were analyzed within $4 \mathrm{~h}$ after collection. All children's guardians signed a consent form approved by Committee for Ethics in Human Research of the Institute of Biomedical Sciences, University of São Paulo (Process $\mathrm{N}^{\circ} \mathrm{CEH} / 678$ ).

\section{Bacterial morphotypes from pulp necrotic and fistula samples}

Bacterial morphotypes were directly determined from collected samples by using Gram and BrownBrenn staining. The stained smears were observed and photographed with a light microscopy (1000 X DMIL Leica, Wetzlar, Germany).

\section{Bacterial DNA detection from pulp and fistula samples \\ Clinical samples were collected and resuspended} in $100 \mu \mathrm{L}$ of sterile ultrapure water (Milli-Q, Millipore, Bedford, MA, USA) and boiled for $10 \mathrm{~min}$. After centrifugation, the supernatant (DNA) was obtained and stored at $-80^{\circ} \mathrm{C}$. DNA concentration and purity were determined by spectrophotometer $\left(A_{260 \mathrm{~nm}}\right)$ and electrophoresis in $1 \%$ agarose gel.

PCR assays were performed in a thermal cycler (Perkin Elmer Gene Amp PCR System 2400, Norwalk, CT, USA) with final volumes of $25 \mu \mathrm{L}$ containing $1 \mathrm{X}$ PCR buffer, $0.2 \mathrm{mM}$ of dNTP mixture, $0.4 \mu \mathrm{M}$ of each primer, $50 \mathrm{mM} \mathrm{MgCl}, 0.5 \mathrm{U}$ Platinum Taq DNA polymerase (Invitrogen do Brasil, Sao Paulo, $\mathrm{SP}$, Brazil), and $1 \mathrm{ng}$ DNA. The respective primers, amplification conditions, and amplicon sizes are described in Table 1. A universal primers pair was used to verify the presence of DNA in all samples.

PCR products were analyzed by electrophoresis $(70 \mathrm{~V}, 2 \mathrm{~h})$ in $1 \%$ agarose gel visualized and photographed under UV light. 1-kb DNA ladder was used as molecular marker. DNA from Enterococcus faecalis ATCC 29212, Aggregatibacter actinomycetemcomitans ATCC 29522, Fusobacterium nucleatum ATCC 25586, Porphyromonas gingivalis ATCC 33277, Porphyromonas endodontalis ATCC 35406, Prevotella intermedia ATCC 25611, Prevotella nigrescens ATCC 33563, Dialister pneumosintes ATCC 33048, Tannerella forsythia ATCC 43037, Eikenella corrodens ATCC 23834, Treponema denticola ATCC 33520, and Campylobacter rectus ATCC 33238 were used as positive controls. In all PCR reactions, sterile water was used as negative control instead of DNA.

\section{Statistical analysis}

The cumulative frequency of distribution and chi-square test were used to verify the bacterial occurrence vs. age and sex. $P$-values less than 0.05 were considered as statistically significant.

\section{RESULTS}

In this study, the lower molar teeth showed a high incidence of pulp necrosis $(66 \%)$, followed by upper molars $(24.1 \%)$ and incisors $(4.7 \%)$. The presence of fistulas was often observed at upper molars $(57.4 \%)$, followed by lower molars $(28.6 \%)$ and upper central incisor (14.3\%). Enterococcus spp. and $P$. gingivalis were prevalent in necrotic pulp of children from 2 to 5 years old, followed by children from 6 to 9 years and 10 to 12 years old. High bacterial numbers showing statistically significant values among boys from 6 to 9 years old 
$(P=0.0520)$ and from 10 to 12 years $(P=0.0261)$ were observed (Table 2).

Different bacterial morphotypes in necrotic pulp and fistula samples were observed. Gram-positive cocci were predominant $(81.8 \%)$, followed by gramnegative coccobacilli (49\%) and gram-positive bacilli (15.5\%) (Figure 1A). In addition, the occurrence of gram-positive cocci and gram-negative coccobacilli did not present statistically significant values for sex or age $(P=0.7380)$. Associations of different bacterial morphotypes were also observed (Figure 1B).

Bacterial DNA was detected in 88 out of 103 necrotic pulps and in 7 fistula samples by using the universal primers. In necrotic pulp samples, Enterococcus spp. (50\%), P. gingivalis (48.9\%) and $F$. nucleatum (25\%) were predominantly found (Figure 2A). The occurrence of Enterococcus

Table 1- Species-specific primers and amplification conditions used for bacterial detection

\begin{tabular}{|c|c|c|c|c|}
\hline Microorganisms & $\begin{array}{l}\text { Sequence } \\
5^{\prime}---->3^{\prime}\end{array}$ & Amplicon & $\begin{array}{l}\text { Amplification } \\
\text { cycles }\end{array}$ & Reference \\
\hline Prevotella intermedia & $\begin{array}{l}\text { TTT GTT GGG GAG TAAAGC GGG } \\
\text { TCAACA TCT CTG TAT CCT GCG T }\end{array}$ & 600 & $\begin{array}{l}30 \text { cycles: } \\
94^{\circ} \mathrm{C} 30 \mathrm{sec} \\
50^{\circ} \mathrm{C} 30 \mathrm{sec} \\
72^{\circ} \mathrm{C} 30 \mathrm{sec}\end{array}$ & 11 \\
\hline Prevotella nigrescens & $\begin{array}{l}\text { ATG AAA CAAAGG TTT TCC GGT AAG } \\
\text { CCC ACG TCT CTG TGG GCT GCG A }\end{array}$ & 804 & $\begin{array}{l}30 \text { cycles: } \\
94^{\circ} \mathrm{C} 30 \mathrm{sec} \\
60^{\circ} \mathrm{C} 1 \mathrm{~min} \\
72^{\circ} \mathrm{C} 2 \mathrm{~min}\end{array}$ & 11 \\
\hline $\begin{array}{l}\text { Porphyromonas } \\
\text { endodontalis }\end{array}$ & $\begin{array}{l}\text { GCT GCA GCT CAA CTG TAG TC } \\
\text { CCG CTT CAT GTC ACC ATG TC }\end{array}$ & 672 & $\begin{array}{l}30 \text { cycles: } \\
94^{\circ} \mathrm{C} 30 \mathrm{sec} \\
60^{\circ} \mathrm{C} 30 \mathrm{sec} \\
72^{\circ} \mathrm{C} 30 \mathrm{sec}\end{array}$ & 11 \\
\hline Porphyromonas gingivalis & $\begin{array}{l}\text { AGG CAG CTT GCC ATA CTG CG } \\
\text { ACT GTT AGC AAC TAC CGA TGT }\end{array}$ & 404 & $\begin{array}{l}30 \text { cycles: } \\
94^{\circ} \mathrm{C} 30 \mathrm{sec} \\
60^{\circ} \mathrm{C} 30 \mathrm{sec} \\
72^{\circ} \mathrm{C} 30 \mathrm{sec}\end{array}$ & 11 \\
\hline Tannerella forsythia & $\begin{array}{l}\text { GCG TAT GTA ACC TGC CCG CA } \\
\text { TGC TTC AGT GTC AGT TAT ACC T }\end{array}$ & 600 & $\begin{array}{l}30 \text { cycles: } \\
94^{\circ} \mathrm{C} 30 \mathrm{sec} \\
60^{\circ} \mathrm{C} 30 \mathrm{sec} \\
72^{\circ} \mathrm{C} 30 \mathrm{sec}\end{array}$ & 18 \\
\hline Fusobacterium nucleatum & $\begin{array}{l}\text { CAAATG CTT GTG TCAATA ATA CT } \\
\text { TTT AGA AGAAAT GGT AGA ATAAT }\end{array}$ & 500 & $\begin{array}{l}30 \text { cycles: } \\
94^{\circ} \mathrm{C} 30 \mathrm{sec} \\
40^{\circ} \mathrm{C} 30 \mathrm{sec} \\
72^{\circ} \mathrm{C} 30 \mathrm{sec}\end{array}$ & 23 \\
\hline Treponema denticola & $\begin{array}{l}\text { TAA TAC CGA ATG TGC TCA TTT ACA T } \\
\text { TCA AAG AAG CAT TCC CTC TTC TTC TTA }\end{array}$ & 316 & $\begin{array}{l}30 \text { cycles: } \\
94^{\circ} \mathrm{C} 30 \mathrm{sec} \\
60^{\circ} \mathrm{C} 30 \mathrm{sec} \\
72^{\circ} \mathrm{C} 30 \mathrm{sec}\end{array}$ & 18 \\
\hline Eikenella corrodens & $\begin{array}{l}\text { CTA ATA CCG CAT ACG TCC TAA G } \\
\text { CTA CTAAGC AAT CAA GTT GCC C }\end{array}$ & 700 & $\begin{array}{l}30 \text { cycles: } \\
94^{\circ} \mathrm{C} 30 \mathrm{sec} \\
45^{\circ} \mathrm{C} 30 \mathrm{sec} \\
72^{\circ} \mathrm{C} 30 \mathrm{sec}\end{array}$ & 18 \\
\hline Campylobacter rectus & $\begin{array}{l}\text { TTT CGG AGC GTAAAC TCC TTT TC } \\
\text { TTT CTG CAA GCA GAC ACT CTT }\end{array}$ & 600 & $\begin{array}{l}30 \text { cycles: } \\
94^{\circ} \mathrm{C} 30 \mathrm{sec} \\
50^{\circ} \mathrm{C} 30 \mathrm{sec} \\
72^{\circ} \mathrm{C} 30 \mathrm{sec}\end{array}$ & 18 \\
\hline Enterococcus spp. & $\begin{array}{l}\text { TACTGACAAACCATTCATGATG } \\
\text { AACTTCGTCACCAACGCGAAC }\end{array}$ & 112 & $\begin{array}{l}30 \text { cycles: } \\
94^{\circ} \mathrm{C} 30 \mathrm{sec} \\
50^{\circ} \mathrm{C} 30 \mathrm{sec} \\
72^{\circ} \mathrm{C} 1 \mathrm{~min}\end{array}$ & 12 \\
\hline Dialister pneumosintes & $\begin{array}{l}\text { TTC TAA GCA TCG CAT GGT GC } \\
\text { GAT TTC GCT TCT CTT TGT TG }\end{array}$ & 1105 & $\begin{array}{l}30 \text { cycles: } \\
94^{\circ} \mathrm{C} 30 \mathrm{sec} \\
55^{\circ} \mathrm{C} 1 \mathrm{~min} \\
72^{\circ} \mathrm{C} 2 \mathrm{~min}\end{array}$ & 22 \\
\hline $\begin{array}{l}\text { Aggregatibacter } \\
\text { actinomycetemcomitans }\end{array}$ & $\begin{array}{l}\text { CCG GAC GTT AGC AGG AAA TTG } \\
\text { TAA CGC CAC ATG AAA CAC TTC }\end{array}$ & 3500 & $\begin{array}{c}30 \text { cycles: } \\
94^{\circ} \mathrm{C} 30 \mathrm{sec} \\
56^{\circ} \mathrm{C} 30 \mathrm{sec} \\
72^{\circ} \mathrm{C} 30 \mathrm{sec}\end{array}$ & 24 \\
\hline 16S rRNA universal primers & $\begin{array}{l}\text { AGA GTT TGA TCC TGG CTC AG } \\
\text { GGC TAC CTT GTT ACG ACT T }\end{array}$ & 3480 & $\begin{array}{l}30 \text { cycles: } \\
94^{\circ} \mathrm{C} 30 \mathrm{sec} \\
58^{\circ} \mathrm{C} 30 \mathrm{sec} \\
72^{\circ} \mathrm{C} 30 \mathrm{sec}\end{array}$ & 8 \\
\hline
\end{tabular}


Table 2- Bacterial detection from necrotic pulp (88) and fistula (7) samples of children

\begin{tabular}{|c|c|c|c|c|c|c|c|}
\hline \multirow[t]{3}{*}{ Microorganisms } & \multicolumn{6}{|c|}{ Age (years) and sex } & \multirow[t]{3}{*}{ Total } \\
\hline & \multicolumn{2}{|c|}{2 to 5} & \multicolumn{2}{|c|}{6 to 9} & \multicolumn{2}{|c|}{10 to 12} & \\
\hline & B & G & B & G & B & G & \\
\hline \multicolumn{8}{|l|}{ Necrotic pulp } \\
\hline Enterococcus spp. & 15 & 7 & 8 & 8 & 4 & 2 & 44 \\
\hline Porphyromonas gingivalis & 14 & 4 & 9 & 9 & 4 & 3 & 43 \\
\hline Fusobacterium nucleatum & 7 & 4 & 5 & 4 & 2 & 0 & 22 \\
\hline Prevotella nigrescens & 2 & 0 & 0 & 3 & 3 & 2 & 10 \\
\hline Prevotella intermedia & 1 & 1 & 1 & 1 & 1 & 0 & 5 \\
\hline Treponema denticola & 1 & 0 & 0 & 2 & 0 & 0 & 3 \\
\hline Tannerella forsythia & 0 & 0 & 0 & 2 & 0 & 0 & 2 \\
\hline Eikenella corrodens & 0 & 1 & 1 & 0 & 0 & 0 & 2 \\
\hline Campylobacter rectus & 0 & 0 & 0 & 2 & 0 & 0 & 2 \\
\hline Porphyromonas endodontalis & 0 & 0 & 1 & 0 & 0 & 0 & 1 \\
\hline Total & 40 & 17 & 25 & 31 & 14 & 7 & 134 \\
\hline \multicolumn{8}{|l|}{ Fistula } \\
\hline Enterococcus spp. & 0 & 0 & 0 & 0 & 1 & 1 & 2 \\
\hline Porphyromonas gingivalis & 1 & 0 & 0 & 1 & 1 & 0 & 3 \\
\hline Fusobacterium nucleatum & 1 & 0 & 0 & 0 & 0 & 0 & 1 \\
\hline Prevotella nigrescens & 0 & 0 & 0 & 1 & 0 & 0 & 1 \\
\hline Dialister pneumosintes & 0 & 0 & 0 & 1 & 0 & 0 & 1 \\
\hline Total & 2 & 0 & 0 & 3 & 2 & 1 & 8 \\
\hline
\end{tabular}

B: boys; G: girls
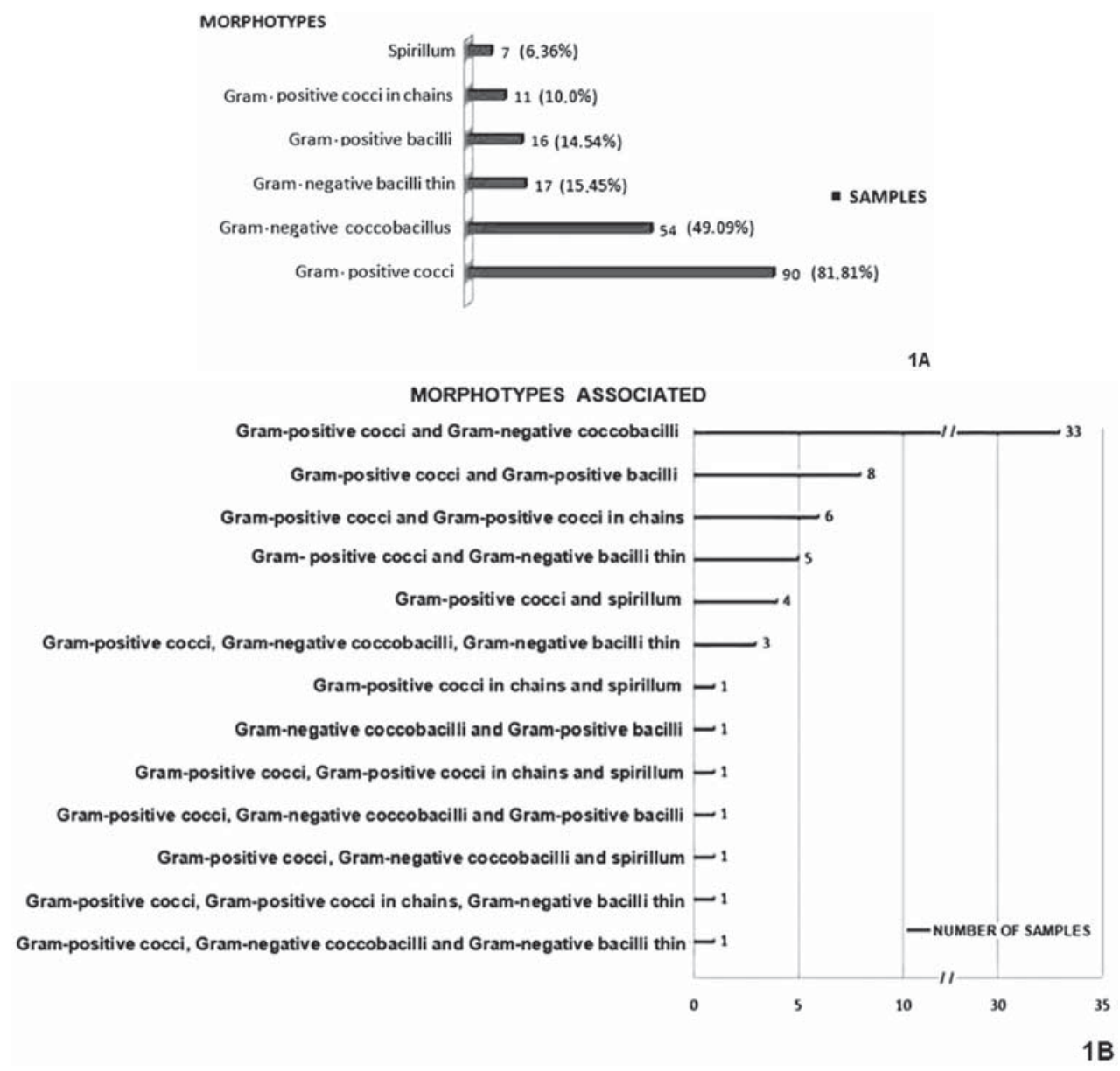

Figure 1- Bacterial morphotypes observed in 88 necrotic pulp and 7 fistula samples. (A) Gram and Brown-Brenn staining. (B) Bacterial morphotypes in association 


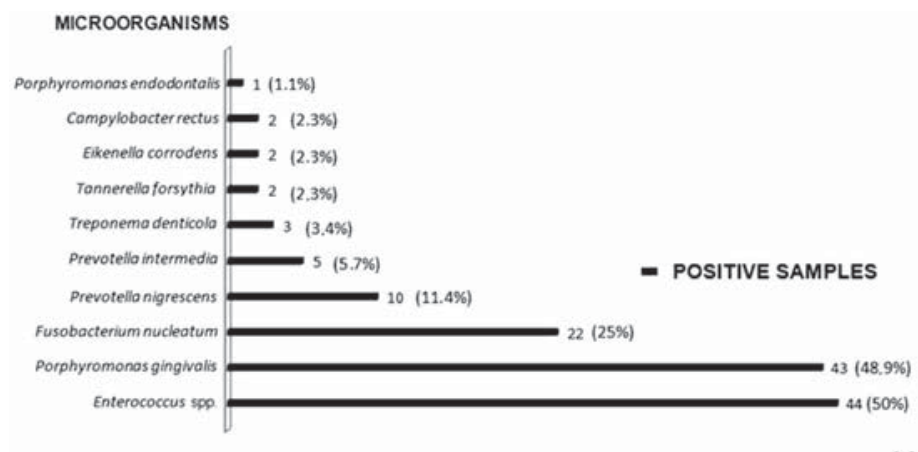

\section{MICROORGANISMS ASSOCIATED}

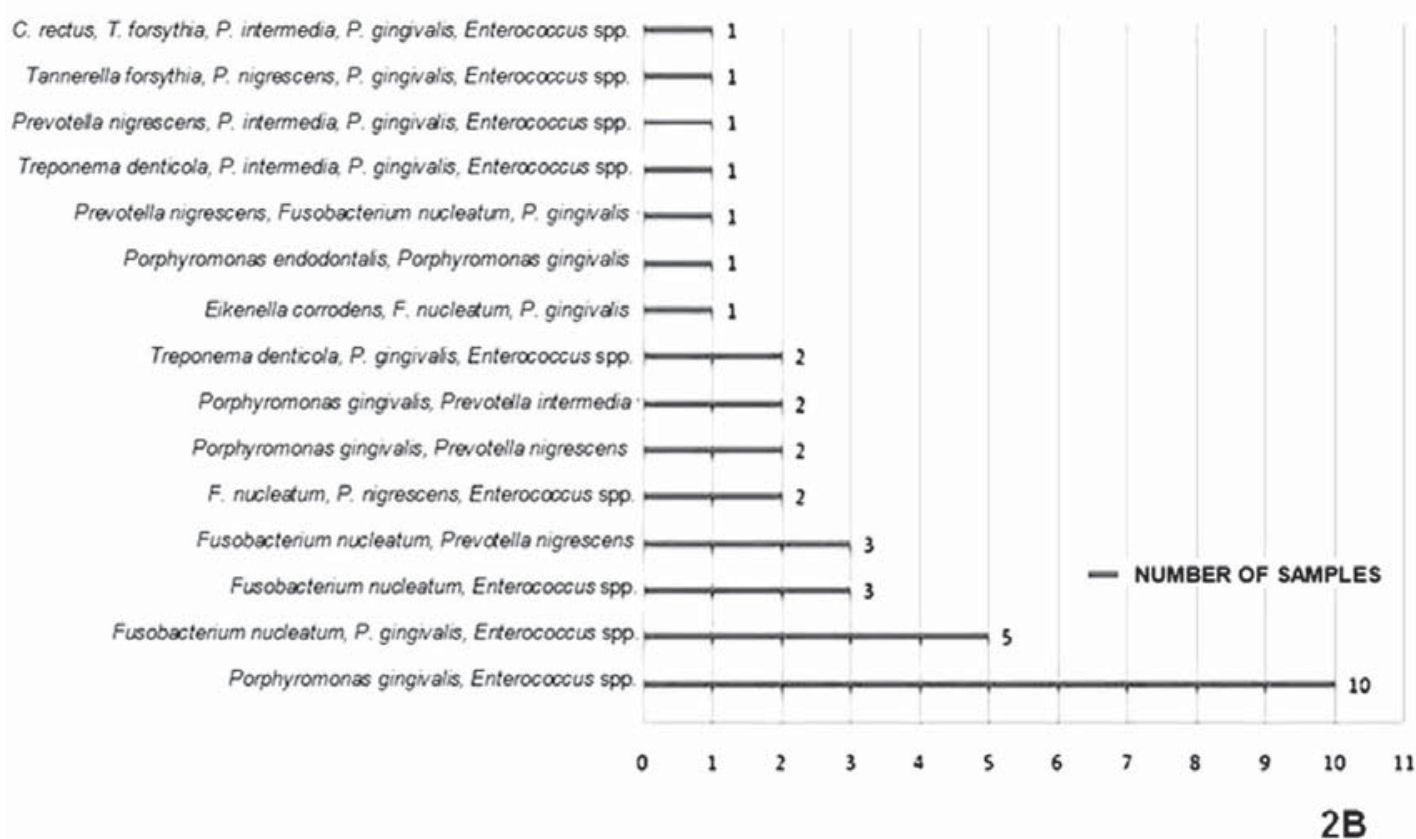

Figure 2- Bacterial detection by PCR in 88 necrotic pulps of deciduous teeth. (A) Bacteria detected. (B) Bacterial association

spp. was higher in boys than girls and presented statistically significant values $(P=0.0297)$; however, no significant difference regarding age $(P=0.2994)$ was observed. In Figure $2 \mathrm{~B}$, the bacterial associations are observed.

Three out of seven fistula samples harbored $P$. gingivalis, two samples Enterococcus spp., and, one sample, $F$. nucleatum, $P$. nigrescens and $D$. pneumosintes. In addition, in two fistulas, $P$. gingivalis was found associated with Enterococcus spp. and $F$. nucleatum, and $P$. nigrescens with $D$. pneumosintes. Pulp or fistula samples did not harbor A. actinomycetemcomitans.

\section{DISCUSSION}

In this study, children presented high incidence of dental caries with necrotic pulp at mandible molars. It may be explained by the food retention and poor oral hygiene in children of this age, producing large accumulation of dental biofilm².

In adults, the occurrence of bacterial morphotypes in primary endodontic infections has been described, and they are represented by cocci, bacilli, spirillum and filamentous forms ${ }^{19}$. In children, the presence of different morphotypes in oral infections of primary teeth, such as caries followed by pulp necrosis, has also been observed ${ }^{20}$. Studies have shown that in root canals of primary teeth with necrotic pulp there is predominance of anaerobic microorganisms, similar to the microbiota of permanent teeth ${ }^{21}$. In addition, the presence of different microorganisms in canal or necrotic pulp can represent the maintenance of infection or any synergistic infection.

Gram-positive cocci and gram-negative coccobacilli appear to be able to colonize necrotic pulp and fistula tissues alone or synergistically, and may collaborate for the maintenance of infection ${ }^{16}$. The lack of endodontic treatment may alter the development of permanent tooth and, also, increase root resorption, leading to premature loss of deciduous teeth.

Different bacterial species belonging to genera Prevotella, Porphyromonas, Fusobacterium, Treponema, Campylobacter, Enterococcus, Tannerella and Dialister have been identified in 
adults with primary endodontic infections ${ }^{14,22}$.

In this study, the primers used presented high sensitivity for detecting enterococci ${ }^{10}$ from root canal. The presence of Enterococcus spp. was observed in $50 \%$ of pulp necrotic samples, and most of them (19\%) were not associated with other bacteria; it may lead to the progression of a chronic disease ${ }^{14}$. On the other hand, Siqueira, et al. $^{20}$ (2002) identified the presence of $E$. faecalis in root canal samples $(7.5 \%)$ and asymptomatic lesions $(11.5 \%)$ by using a checkerboard DNA-DNA hybridization.

Studies have shown that enterococci isolated from foods are able to colonize the oral cavity, suggesting that these microorganisms can survive in dental biofilm, participating of endodontic infections ${ }^{1,25}$. In addition, it was reported that $E$. faecalis isolated from necrotic root canals and fecal material of adults with endodontic infection did not present any genetic similarity, suggesting an exogenous contamination, mainly by industrial food $^{25}$. On the other hand, enterococci have been found in $52.5 \%$ of dairy foods, such as milk and cheese, and it was suggested that the consumption of foods containing enterococci could collaborate with the increase of $E$. faecalis in necrotic pulp; however, it is not fully defined ${ }^{6}$.

The high prevalence of Enterococcus spp. and $P$. gingivalis observed in necrotic pulp of children from 2 to 5 years old can be explained by difficulty to perform effective tooth brushing. Microbiological studies showing the bacterial prevalence in deciduous teeth with pulp infections are scarce. Since $E$. faecalis can acquire resistance to antimicrobials commonly used in endodontic treatment ${ }^{15}$, the detection of this microorganism from different endodontic infections is of interest.

The presence of black-pigmented anaerobic rods, such as Porphyromonas spp. and Prevotella spp. has been associated with primary endodontic infections and acute periradicular abscesses ${ }^{5}$. It may suggest a possible cross infection between root canal and periodontal pocket. In addition, several possible ways to access the pulp are suggested, such as root canals, dentin, cement, and physiological areas of root resorption ${ }^{14}$.

The presence of $P$. gingivalis has been shown in endodontic infections affecting approximately $27 \%$ of the deciduous teeth ${ }^{8,27}$; however, in this study, this microorganism was observed in $49 \%$ of the analyzed necrotic pulps, and this result is similar to that found in adults ${ }^{22}$. In addition, pulp samples harbored $P$. nigrescens $(11 \%), P$. intermedia $(6 \%)$ and $P$. endodontalis $(11 \%)$, and, certainly, their association with other bacteria may contribute to the pathogenicity and maintenance of the infectious process.

Bacterial associations such as Porphyromonas
spp./Prevotella spp. and $P$. gingivalis/Enterococcus spp. were detected, suggesting that these microorganisms are able to survive in necrotic tissues, alone or in association. The availability of nutrients, low oxygen tension and bacterial interactions are important ecological determinants for these bacteria in root canals with necrotic pulp ${ }^{24}$.

Fusobacterium nucleatum colonizes the oral cavity, and has often been isolated from primary endodontic infections in adult patients ${ }^{7}$. This microorganism has been found in between $4 \%$ and $18 \%$ of the pulp infections of deciduous teeth ${ }^{27}$. In this study, $F$. nucleatum was found in $25 \%$ of the necrotic pulps, alone or in association with Enterococcus spp. and/or $P$. gingivalis. Synergistic association between $F$. nucleatum and $P$. gingivalis has been described in various forms of periodontitis, and associated to the dental biofilm formation ${ }^{18}$.

Spirochetes such as Treponema denticola and Treponema socranskii have been detected in $77 \%$ of adults with primary endodontic infections, and both bacteria are considered prevalent in these infectious processes. Species of Treponema have been found in $2.6 \%$ of the pulp infections of deciduous teeth ${ }^{27}$. Notwithstanding, P. gingivalis and Treponema spp. are considered important microorganisms in patients with adult periodontitis ${ }^{22}$, but the presence of $T$. denticola has been detected in small proportion and in association with $P$. gingivalis, Enterococcus spp. or $P$. nigrescens. It is suggested that bacterial association contributes to the pathogenic biofilms formation. In this study, the low detection rate (2.3\%) of Tannerella forsythia, Campylobacter rectus and Eikenella corrodens is in accordance with the literature ${ }^{17}$. Recently, Campylobacter spp. was detected in $3.3 \%$ of children with endodontic abscesses ${ }^{27}$.

Dialister pneumosintes has been observed in children and young adults with gingivitis and periodontitis, as well as lung and brain abscesses, and root canal 4 . In this study, only one fistula sample harbored $D$. pneumosintes in association with $P$. nigrescens. Both microorganisms have been isolated from primary endodontic infections, mainly in periapical lesions, and their presence in association can suggest any synergistic effect in the infected sites.

Aggregatibacter actinomycetemcomitans is a capnophilic bacteria which is considered a causal agent of localized aggressive periodontitis in young adults; the absence of this bacterium in the analyzed samples can be explained by the fact that this microorganism is not able to survive in the root canal $^{18}$

Studies have associated the failure of endodontic treatment in adults with the presence of $E$. faecalis. This microorganism shows high resistance to calcium hydroxide and irrigating solutions commonly used in 
endodontic treatment ${ }^{12,15}$. In addition, this bacterial resistance may also occur in treatment of primary teeth, producing a persistent infection. On the other hand, it has been pointed out that some chemical substances commonly used in endodontic treatment can produce changes in the physicochemical properties of dentin, microbiota, bacterial adherence and biofilm formation? ${ }^{9}$.

Enterococcus faecalis, $P$. gingivalis and $F$. nucleatum were found in high numbers, and their presence may contribute to the development of chronic infections, such as gingivitis or periodontitis. Since the presence of Enterococcus spp. and $P$. gingivalis in pulp and fistula samples from deciduous teeth was observed, a possible bacterial synergism inside the root canal is suggested, and, certainly, it might increase their resistance against the antimicrobial agents most commonly used in Pediatric Dentistry.

\section{ACKNOWLEDGEMENTS}

The authors thank Marcia Harumi Fukugaiti for her technical support. This study was supported by CNPq grant $N^{\circ} 143056 / 2006-9$ and FAPESP $N^{\circ}$ 08/58738-7. During the course of this work, VN was supported by FAPESP Proc. 08/57330-4.

\section{CONFLICTS OF INTEREST}

The authors declare that there are no conflicts of interest.

\section{REFERENCES}

1- Al-Ahmad A, Maier J, Follo M, Spitzmüller B, Wittmer A, Hellwig $E$, et al. Food-borne enterococci integrate into oral biofilm: an in vivo study. J Endod. 2010;36(11):1812-9.

2- Braga MM, Martignon S, Ekstrand KR, Ricketts DN, Imparato JC, Mendes FM. Parameters associated with active caries lesions assessed by two different visual scoring systems on occlusal surfaces of primary molars a multilevel approach. Community Dent Oral Epidemiol. 2010;38(6):549-58.

3- Cuoghi AO, Bertoz FA, Mendonca MR, Santos EC. Loss of space and dental arch length after the loss of the lower first primary molar: a longitudinal study. J Clin Pediatr Dent. 1998;22(2):11720.

4- Doan N, Contreras A, Flynn J, Slots J, Chen C. Molecular Identification of Dialister pneumosintes in subgingival plaque of humans. J Clin Microbiol. 2000;38(8):3043-7.

5- Fouad AF, Barry J, Caimano M, Clawson M, Zu Q, Carver R, et al. PCR-based identification of bacteria associated with endodontic infections. J Clin Microbiol. 2002;40(9):3223-31.

6- Gomes BP, Pinheiro ET, Sousa EL, Jacinto RC, Zaia AA, Ferraz $\mathrm{CC}$, et al. Enterococcus faecalis in dental root canals detected by culture and by polymerase chain reaction analysis. Oral Surg Oral Med Oral Pathol Oral Radiol Endod. 2006;102(2):247-53.

7- Jacinto RC, Montagner F, Signoretti FGC, Almeida GC, Gomes BPFA. Frequency, microbial interactions and antimicrobial susceptibility of Fusobacterium nucleatum and Fusobacterium necrophorum isolated from primary endodontic infections. J Endod. 2008;34(12):1451-6.
8- Ito IY, Matoba F Junior, Paula-Silva FWG, Silva LAB, Leonardo MR, Nelson P Filho. Microbial culture and checkerboard DNA-DNA hybridization assessment of bacteria in root canals of primary teeth pre- and post-endodontic therapy with a calcium hydroxide/ chlorhexidine paste. Int J Paed Dent. 2011;21(5):353-60.

9- Kishen A, Sum C, Mathew S, Lim C. Influence of irrigation regimens on the adherence of Enterococcus faecalis to root canal dentin. J Endod. 2008;34(7):850-4.

10- Morabito A, Defabianis P. A SEM investigation on pulpalperiodontal connections in primary teeth. ASDC J Dent Child. 1992;59(1):53-7.

11- Nandakumar R, Mirchandani R, Fouad A. Primer sensitivity: can it influence the results in Enterococcus faecalis prevalence studies? Oral Surg Oral Med Oral Pathol Oral Radiol Endod. 2007;103(3):429-32.

12- Ohara PK, Torabinejad M, Kettering JD. Antibacterial effects of various endodontic irrigants on selected anaerobic bacteria. Endod Dent Traumatol. 1993;9(3):95-100.

13- Önçag O, Cogulu D, Uzel A. Efficacy of various intracanal medicaments against Enterococcus faecalis in primary teeth: an in vivo study. J Clin Pediatr Dent. 2006;30(3):233-7.

14- Ozbek SM, Ozbek A, Erdogaan AS. Analysis of Enterococcus faecalis in samples from Turkish patients with primary endodontic infections and failed endodontic treatment by real time PCR SYBR green method. J Appl Oral Sci. 2009;17(5):370-4.

15- Queiroz AM, Nelson-Filho P, Silva LA, Assed S, Silva RA, Ito IY. Antibacterial activity of root canal filling materials for primary teeth: zinc oxide and eugenol cement, Calen paste thickened with zinc oxide, Sealapex and EndoRez. Braz Dent J. 2009;20(4):290-6. 16- Rocha CT, Rossi MA, Leonardo MR, Rocha LB, Nelson-Filho P, Silva LA. Biofilm on the apical region of root in primary teeth with vital and necrotic pulps with or without radiographically evident apical pathosis. Int Endod J. 2008;41(4):664-9.

17- Ruviére DB, Leonardo MR, Silva LAB, Ito IY, Nelson-Filho P. Assessment of the microbiota in root canals of human primary teeth by checkerboard DNA-DNA hybridization. J Dent Child (Chic). 2007;74(2):118-23.

18- Saito Y, Fujii R, Nakagawa K, Kuramitsu HK, Okuda K, Ishihara K. Stimulation of Fusobacterium nucleatum biofilm formation by Porphyromonas gingivalis. Oral Microbiol Immunol. 2008;23(1):16.

19- Siqueira JF Jr, Rôças IN, Lopes HP. Patterns of microbial colonization in primary root canal infections. Oral Surg Oral Med Oral Pathol Oral Radiol Endod. 2002;93(2):174-8.

20- Siqueira JF, Roças IN, Souto R, Uzeda M, Colombo AP. Actinomyces species, streptococci, and Enterococcus faecalis in primary root canal infections. J Endod. 2002;28(3):168-72.

21- Silva LAB, Nelson-Filho P, Faria G, Souza-Gugelmin MCM, Ito IY. Bacterial profile in primary teeth with necrotic pulp and periapical lesions. Braz Dent J. 2006;17(2):144-8.

22- Slots J, Ashimoto A, Flynn MJ, Li G, Chen C. Detection of putative periodontal pathogens in subgingival specimens by $16 \mathrm{~S}$ ribosomal DNA amplification with the polymerase chain reaction. Clin Infect Dis. 1995;20(Suppl 2):S304-7.

23- Sundqvist G. Associations between microbial species in dental root canal infections. Oral Microbiol Immunol. 1992;7(5):257-62. 24- Sundqvist G, Johansson E, Sjögren U. Prevalence of blackpigmented Bacteroides species in root canal infections. J Endod. $1989 ; 15(1): 13-9$.

25- Tronstad L, Kreshtool D, Barnett F. Microbiological monitoring and results of treatment of extraradicular endodontic infection. Endod Dent Traumatol. 1990;6(3):129-36.

26- Van Winkelhoff AJ, Carlee AW, Graaff J. Bacteroides endodontalis and other black-pigmented Bacteroides species in odontogenic abscesses. Infect Immun. 1985;49(3):494-7.

27- Yang QB, Fan LN, Shi Q. Polymerase chain reaction-denaturing gradient gel electrophoresis, cloning, and sequence analysis of bacteria associated with acute periapical abscesses in children. J Endod. 2010;36(2):218-23. 